\section{Enzymatic Isolation of Protoplasts from the Liverwort Sphaerocarpos donnellii Aust.}

\section{Otto Schieder and Gerhard Wenzel}

Max-Planck-Institut für Züchtungsforschung, Köln-Vogelsang, Abt. Straub

(Z. Naturforsch. 72 b, 479-480 [1972]; received January 24, 1972)

Fusion of free plant protoplasts opens possibilities to obtain new genetical and cytological results. Haploid material is superior to diploid for such experiments. Haploid protoplasts of Petunia ${ }^{1}$ were isolated, but so far further development of these haploid protoplasts could not be achieved. Isolated moss protoplasts have been shown to be capable of regeneration ${ }^{2}$, and therefore would offer better material. Furthermore it is possible to easily commence here with axenic cultures. The composition of moss cell walls, however, differs strongly from those of higher plants ${ }^{3-5}$. Therefore only small quantities of protoplasts have been obtained by complicated mechanical methods ${ }^{2}$.

This paper deals with the enzymatic degradation of cell walls and the isolation of protoplasts from normal and auxotrophic Sphaerocarpos donnellii Aust.

Female plants of the wild strain were grown under sterile conditions on Benecke agar in petri dishes (temperature $18 \pm 1{ }^{\circ} \mathrm{C}$, light intensity $2800 \mathrm{lux}, 12 \mathrm{~h}$ per day). The plants were propagated vegetatively from thallus tips. Cell walls from plants grown on completely inorganic medium were digested more effectively than those grown on agar supplemented with $1 \%$ glucose and $0.05 \%$ peptone. This suggests an increased synthesis of cell wall material in supplemented medium, an assumption that is supported by higher dry weights ${ }^{6}$.

Optimal plasmolysis of Sphaerocarpos protoplasts was achieved in $0.4 \mathrm{M}$ mannitol. Generally, the enzyme was dissolved directly in the plasmolyticum without addition of buffer. $\mathrm{pH}$ was adjusted with $0.1 \mathrm{~N} \mathrm{HCl}$. The plants were not visibly damaged down to $\mathrm{pH} 4$. The material was incubated in a shaking waterbath between 25 and $33{ }^{\circ} \mathrm{C}$, higher temperatures caused denaturation of the cytoplasm. As long as the protoplasts were located in the thallus, the shaking frequency was 140 strokes $/ \mathrm{min}$, with an amplitude of $5.7 \mathrm{~cm}$. The frequency was reduced to 65 strokes and amplitude to $2.4 \mathrm{~cm}$, when the first protoplasts appeared.

For digestion of the cell walls a number of enzymes were tested singly, in simultaneous and/or successive combinations. The glucosidases, hyaluronidase (EC 3.2.1.35) and lysozyme (EC 3.2.1.17), as well as pronase P (Serva, Heidelberg) and lipase (EC 3.1.1.3) did not produce protoplasts. Some $\beta$-glucuronidases (EC 3.2.1.31) had diverging effects: $\beta$-glucuronidase from bovine liver (Merck, Darmstadt, or Schuchardt, Munich), from E. coli type II (Sigma, St. Louis), from

Requests for reprints should be sent to Dr. OTto SchiEDER, Max-Planck-Institut für Züchtungsforschung, D-5000 $K \ddot{l n} 30$. marine mollusks, and as acetone dried powder (both Schuchardt) were ineffective.

In Table I some of those enzyme combinations are presented which caused visible changes in the wall structure or liberated protoplasts. A mixture of $0.75 \%$ pectinase (macerozyme), $2 \%$ cellulase (Onozuka, both: Kinki Yakult, Nishinomiya, Japan), and 2\% hemicellu-

\begin{tabular}{|c|c|c|c|c|c|}
\hline $\begin{array}{l}\text { Enzyme } \\
\text { combination }\end{array}$ & $\begin{array}{l}\text { Conc. } \\
{[\%]}\end{array}$ & $\begin{array}{l}\mathrm{T} \\
{\left[{ }^{\circ} \mathrm{C}\right]}\end{array}$ & $\begin{array}{l}t \\
{[\mathrm{~h}]}\end{array}$ & $\mathrm{pH}$ & $\begin{array}{l}\text { Active } \\
\text { protoplasts } \\
\text { per ml }\end{array}$ \\
\hline $\begin{array}{l}\text { Cellulase and } \\
\text { Pectinase }\end{array}$ & $\begin{array}{l}2 \\
0,75\end{array}$ & 30 & 4 & 5,5 & none \\
\hline $\begin{array}{l}\text { Hemicellulase, } \\
\text { Cellulase, and } \\
\text { Pectinase }\end{array}$ & $\begin{array}{l}2 \\
2 \\
0,5\end{array}$ & 30 & 3 & 5,5 & a few \\
\hline $\begin{array}{l}\text { Helicase S } \\
\text { (Suc Helix pomatia) }\end{array}$ & 2,5 & 30 & 1 & 4,5 & none \\
\hline $\begin{array}{l}\text { a) Helicase S } \\
\text { (Suc H.pom.) } \\
\text { b) Cellulase and } \\
\text { Pectinase }\end{array}$ & $\begin{array}{l}2,5 \\
2 \\
0,75\end{array}$ & $\begin{array}{l}30 \\
30\end{array}$ & $\begin{array}{l}1 \\
2\end{array}$ & $\begin{array}{l}4,5 \\
5,5\end{array}$ & $\begin{array}{l}\text { ca. } \\
10-10^{2}\end{array}$ \\
\hline $\begin{array}{l}\text { a) } \beta \text {-Glucuronidase } \\
(H \cdot \text { pom. }) \\
\text { b) Cellulase and } \\
\text { Pectinase }\end{array}$ & $\begin{array}{l}2,5 \\
2 \\
0,75\end{array}$ & $\begin{array}{l}30 \\
30\end{array}$ & $\begin{array}{l}1 \\
2\end{array}$ & $\begin{array}{l}4,5 \\
5,5\end{array}$ & ca. $10^{2}$ \\
\hline $\begin{array}{l}\text { a) } \beta \text {-Glucuronidase } \\
(H . \text { pom. }) \\
\text { b) Cellulase and } \\
\text { Pectinase }\end{array}$ & $\begin{array}{l}2,5 \\
4 \\
0,75\end{array}$ & 30 & 1 & $5,5 \mathrm{ca}$ & $10^{2}-10^{3}$ \\
\hline $\begin{array}{l}\text { a) } \beta \text {-Glucuronidase } \\
(H . \text { pom.) } \\
\text { b) Cellulase and } \\
\text { Pectinase }\end{array}$ & $\begin{array}{l}2,5 \\
6 \\
0,75\end{array}$ & 30 & 1 & 4,5 & ca. $10^{3}$ \\
\hline
\end{tabular}

Tab. 1. Yield of protoplasts from Sphaerocarpos donnellii Aust. after digestion. a) $=$ preincubation, b) $=$ second incubation.

lase (Schuchardt or Sigma) caused swelling and partial degradation of the cell wall. However, a loose texture remained, which allowed only a few protoplasts to escape. Preincubation with helicase from Helix pomatia (L'Industrie Biol. Francaise, Gennevilliers) caused a striking increase in concentration of free protoplasts. Helicase effected fragmentation of the thallus into small parts and single cells, but without further visible damage to the walls. One hour incubation was optimal. A mixture of pectinase and cellulase was added after decantation of helicase. This freed about 100 protoplasts per $\mathrm{ml}$ in two hours, if $1 \mathrm{~g}$ tissue per $5 \mathrm{ml}$ enzyme solution was used. $\beta$-glucuronidase of Helix pomatia (Schuchardt) gave a higher yield, which could be increased further by higher cellulase concentrations $(6 \%)$. The suspension of free protoplasts was filtered through sieves (pore diameters $500 \mu$ and $100 \mu$ ) and centrifuged $(3 \mathrm{~min}$ at $250 \mathrm{~g}$ ). Free protoplasts were recovered from the supernatant. A typical suspension contained about $10^{4}$ free protoplasts. This protoplast concentration is significantly lower than that required 
to grow tobacco protoplasts ${ }^{7}$. The higher regeneration rate of mosses, however, should overcome this disadvantage.

Two different types of protoplasts were distinguishable: smaller protoplasts $(\phi 40 \mu)$ containing many large plastids and others $(\phi 100 \mu)$ with smaller plastids. The large protoplasts were derived mostly from the midribs and basal parts of the thallus. The relative proportions of the two types depended more or less on the age of the cultures used. The maximal protoplast concentration was obtained with $4-6$ week old material. The ratio of large to small protoplasts in

1 G. Wenzel, unpublished.

2 H. H. Binding, Z. Pflanzenphysiol. 55, 305 [1966].

3 C. Bricker and W. T. Doyle, Amer. J. Bot. 51, 666 [1964].

${ }^{4}$ V. S. R. DAS and M. P. RAO, Ind. J. Exp. Biol. 5, 193 [1967]. such supensions is ca. $1: 2$. Two month old plants could only be partially digested and produced mainly large and unstable protoplasts.

To date, two auxotrophic strains could be isolated after x-ray treatment. These strains are nicotinic acid deficient ${ }^{8}$. The isolation of further auxotrophic strains will be undertaken. Protoplasts can be prepared from auxotrophs using the same technique as described above. It should thus be possible to select hybrids if fusion between different auxotrophic strains could be achieved.

5 D. Schulz and H. Lehmann, Cytobiol. 1, 343 [1970].

6 O. Schieder, Z. Pflanzenphysiol. 59, 258 [1968].

7 I. Takebe, G. Labib, and G. Melchers, Naturwissenschaften 58, 318 [1971].

8 O. Schieder, unpublished.

\section{A Rapid Visualization of Kleinschmidt- Type DNA Preparations by Phosphotungstic Acid}

\author{
Michiko Egel-Mitani and Richard Egel \\ Institute of Biology III, University of Freiburg, Germany \\ (Z. Naturforsch. 27 b, 480 [1972] ; received December 17, 1971, revised \\ January 27, 1972)
}

After KleINSCHMIDT and ZAHN ${ }^{1}$ first used protein films to display DNA molecules, their procedure became a standard technique of current nucleic acid research ${ }^{2}$. Preparations by this technique are usually contrasted for electron microscopy by heavy-metal shadowing (two-angle or rotary) or by uranyl ion staining (commonly referred to as positive staining of $\mathrm{DNA}^{3}$ ). Supported by extremely thin carbon films, even DNA preparations without appositional contrast could be observed by bright or dark field electron microscopy ${ }^{4,5}$. Another way for visualizing genetic material was followed by MiLLER et al. ${ }^{6}$. Transcription complexes, consisting of DNA, RNA and protein, were sedimented onto the grids by centrifugation, and contrasted by using phosphotungstic acid (PTA) as a protein specific stain.

During our attempts to characterize DNA from meiotic yeast cells, we also tried MILlER's staining procedure on KLEINSCHMIDT preparations of purified DNA. The result was unexpectedly satisfactory (Fig. $1^{*}$ ). Evidently DNA molecules are sufficiently covered by

Requests for reprints should be sent to Dr. R. EgEL, Institut f. Biologie III d. Universität, BRD-7800 Freiburg, Schänzlestr. 9-11.

1 A. K. KLeinschmidt and R. K. ZAhN, Z. Naturforsch. 14 b, 770 [1959].

2 D. LANG, Phil. Trans. Roy. Soc. Lond. B 261, 151 [1971].

${ }^{3}$ R. W. DAvis et al., in: Methods in Enzymology, vol. 21, (L. Grossman and K. Moldave eds.), Acad. Press, New York 1971. cytochrome c to appear continuously stained by a protein specific dye, yet the protein film is thin enough not to obscure the DNA threads by PTA bound to spread cytochrome c molecules. Photographs of unstained but otherwise comparable preparations showed that PTA caused most of the contrast. Preparations of singlestranded DNA (Fig. 2) were contrasted to about the same extent as double-stranded DNA, so that the degree of strandedness may not be inferred from pictures alone, as was also noticed by KLEINSCHMIDT ${ }^{4}$. Overall contrast was better the thinner the supporting carbon film could be made, though initial reinforcement by collodion ${ }^{4}$ was not used.

The method described here involves considerably less effort than shadow-casting, and may therefore be especially useful in routine work.

Staining procedure: The DNA-containing cytochrome c film is picked up by a carbon coated grid. The water droplet is removed by absolute ethanol. The grid is then touched with filter paper to absorb excess ethanol, dipped immediately, for $60 \mathrm{sec}$, into a freshly prepared mixture (1:1 by volume) of a $4 \%$ aqueous solution of phosphotungstic acid and absolute ethanol, rinsed in $50 \%$ ethanol and in absolute ethanol for 10 sec each, then dried on filter paper.

We are very grateful to Dr. H. FALK for his advice on electron microscopy, and to Mr. D. Fischer for contributing a sample of purified fd DNA. This work was supported by the Deutsche Forschungsgemeinschaft (SFB 46). One of us (M. E.-M.) held a fellowship of the Alexander von Humboldt Stiftung.

4 A. K. Kleinschmidt, Phil. Trans. Roy. Soc. Lond. B. 261, 143 [1971].

5 J. Dubochet et al., J. Ultrastructure Res. 35, 147 [1971].

6 O. L. Miller, JR. et al., Cold Spring Harbor Symp. Quant. Biol. 35, 505 [1970].

7 H. Bujard, J. molecular Biol. 49, 125 [1970].

* Figs. 1 and 2 see Table p. 480 a. 